Space and Place in Administrative Military Regulations of Qing China: An Evaluation of the Legal Type of Zeli

L'espace et le lieu dans les réglementations de l'administration militaire à

l'époque des Qing : une évaluation des zeli comme genre juridique 清代軍事管理規範的空間與地域: 一種法律類型“則例”的演變

\title{
Ulrich Theobald
}

\section{(2) OpenEdition}

\section{Journals}

Electronic version

URL: http://journals.openedition.org/extremeorient/624

DOI: 10.4000/extremeorient.624

ISBN: 978-2-84292-558-1

ISSN: 2108-7105

Publisher

Presses universitaires de Vincennes

\section{Printed version}

Date of publication: 21 November 2016

Number of pages: $183-206$

ISBN: 978-2-84292-556-7

ISSN: 0754-5010

\section{Electronic reference}

Ulrich Theobald, « Space and Place in Administrative Military Regulations of Qing China: An Evaluation of the Legal Type of Zeli », Extrême-Orient Extrême-Occident [Online], 40 | 2016, Online since 21

November 2018, connection on 02 May 2019. URL : http://journals.openedition.org/extremeorient/624 ; DOI : 10.4000/extremeorient.624 


\title{
Space and Place in Administrative Military Regulations of Qing China: An Evaluation of the Legal Type of Zeli
}

\author{
Ulrich Theobald
}

Between 1680 and 1780 the Qing empire vastly expanded its territory by military conquest. In the course of several long-lasting campaigns it had turned out that, for the sake of smoother administration and cutting expenditure, a 'nationwide' arrangement of military regulations was necessary. The compilers of such regulations aligned those of various provincial ones that in some cases differed substantially from each other. In the War Supplies and Expenditure Regulations (Junxu zeli) and the two Weapons and Military Equipment Regulations (Junqi zeli and Gongbu junqi zeli) such standardization was brought about by evening out conflicts between local norms. 1

This article shows under what conditions these regulations came into being and how the compilers unified differing local arrangements to create normative rules for special administrative purposes (zeli). It will be demonstrated that in spite of all attempts at standardization with respect to allowances for troops and persons working in the supply train, as well as in the field of weaponry and equipment of all kinds, their production methods and manufacturing cost the provinces and even the garrisons were still left a considerable degree of autonomy. The military zeli regulations are excellent paradigms to point out how flexibility was combined with judicial reliability, and what shortcomings such administrative regulations might have in the long run.

\section{The legal genre of zeli "regulations and precedents"}

The term zeli is a combination of the words "regulations" (ze) and "precedents" $(l i)$, meaning that a substantial part of the regulations was based on precedent ad-hoc or customary solutions to specific problems arising in daily

1. The word "standardization" is used here to describe a process of defining norms. The word "unification" means that standards were applied 'nationwide'. 
administration. The obligatory nature of the "established regulations" (dingli) gives them a binding character similar to codified law: Officials violating these regulations were subject to sanctions. Iwo Amelung, who describes the creation and use of the "Regulations and Precedents for River Work" (Hegong zeli) therefore stresses that the "[judicial] reliance on precedents was one of the main features of the Qing administration". ${ }^{2}$ It seems therefore justified to call the zeli collections 'canons', rather than using the literal meaning of this word. Yet this does not mean that zeli had the same status as laws. The main difference between the canonized law (as found in the legal code $D a$ Qing lüli and the administrative code Da-Qing huidian) and the zeli was that the latter were created with a certain amount of flexibility which made them adaptable to specific circumstances. Moreover, collections or sets of zeli were to be revised regularly, some every ten years, others in shorter intervals. Zeli were also much more concrete and specified than codified laws, and servedto use a traditional Chinese analogy - as the "meshes" ( $m u$ ) of a greater net structure (gang, i.e. laws) providing the general structure of rule. Some authors compare the zeli with the shili, which constituted a separate and more detailed set of rules and regulations for the administrative code, Da-Qing huidianshili, or with the tiaoli sub-statutes to the law code. ${ }^{3}$ Yet while these two sets of supplementary regulations were indispensable parts of the two canons (even if the Huidian shili collection was published separately), ${ }^{4}$ zeli were autonomous collections regulating detailed administrative matters of individual institutions or jurisdictional areas. ${ }^{5}$ These arguments lead to the conclusion that the term zeli is best translated somewhat ambiguously as "regulations".

Two types of zeli can be found, relatively general regulations with a wide range of specifications of high-level government institutions, mainly the Six Ministries, ${ }^{6}$ and specialized regulations dealing with the organization of specific administrative matters like collecting taxes, arresting fugitives,

2. Amelung 2005: 291.

3. On the law codes and the relation between statutes and sub-statutes, see Head and Wang (2005: 18) who translate the term $l i$ as "codified precedent". In connection with statutory law (lii), li can be called sub-statute, see Bodde and Morris 1967: 63-68.

4. Even the sub-statutes to the Da-Qing lïli (the $l i$ ) were consulted as an individual code before 1707/1727 (with the name Xianxing zeli "Sub-statutes currently operative"). After 1727 they were re-integrated into the canon. See Bodde and Morris 1967: 66-67.

5. A concise discussion on this matter can be found in Xia 1991: 98-100. See also Li 2010: 75.

6. For instance, the (currently operative) administrative regulations of the Ministry of Justice Xingbu xianxing zeli (1680), the administrative regulations of the Court of Colonial Affairs Lifanyuan zeli (1687), of the Ministry of Personnel Libu zeli (1734), 
education, material and labour cost, official discipline, grain transport, or ceremonies. ${ }^{7}$ Apart from zeli regulations valid 'nationwide', there were also provincial regulations (shengli). ${ }^{8}$

A first study of the compilation process of central and provincial zeli texts was written by Tanii Yōko. ${ }^{9}$ She focuses on the early phase of the zeli compilations during the Kangxi reign (1662 - 1722). The most intensively studied regulations are those on handicrafts and construction, Jiangzuo zeli. A brief introduction to this type of regulations can be found in a proceedings volume with a collection of papers on this topic, ${ }^{10}$ as well as in an article by Christine Moll-Murata that gives quite a good insight into the nature of zeli regulations. ${ }^{11}$ Apart from these studies, literature on zeli is scarce. ${ }^{12}$

The terminology of regulations "based on precedents" (as will be seen later, not all established regulations had precedents) is somewhat confuse. The vague terms shiyi, zhangcheng and zhouzhang ("rules", "statutes", "regulations", and the like) denote ad-hoc regulations written down for the purpose of providing a kind of guide for officials involved, but also of giving account to higher authorities. In a next legislative step these were acknowledged and confirmed by higher authorities, like the Ministry in question. The terms for such "established" or "established regulations" were dingli or chengli. Zeli finally was the highest status of regulations and had, as far as can be seen from the

of the Ministry of Works Gongbu zeli (1749), or that of the Ministry of Revenue Hubu zeli (1776).

7. Like the regulations for minting of the Ministry of Revenue Hubu guzhu zeli (1769) or the regulations of the Ministry of Personnel for the selection and appointment of state officials Libu quanxuan zeli (1886) or the disciplinary regulations of the Six Ministries Liubu chufen zeli (1887). Not all texts of this type include the word zeli in the title. The extensive military administration regulations Zhongshu zhengkao from 1672 (revised 1825 ) is such a case in point. Other examples are Tongzheng bianlan, a manual on copper administration from about 1830 or the Caoyun quanshu, a manual from 1845 on the transport of tribute grain along the Grand Canal, the regulations for taxation Fuyi quanshu (1732), the comprehensive regulations on the ceremonies of the dynasty Da-Qing tongli (1757) or the regulations for public schools Xuezheng quanshu (1774).

8. Like Hunan sheng li or Jinzheng jiyao (on Shanxi). This issue is treated in the contribution of Wang Zhiqiang in this volume.

9. Tanii 1995: 137-239.

10. Amelung 2005: 291.

11. Moll-Murata 2001: 255-271.

12. A very short bibliography on zeli texts can be found in Wilkinson 2012: 843-844. Most helpful is Metzger (1973: 197-205), where the zeli regulations are called "fully established precedents". See also the following articles: Li 2006: 160-161, 165; Li 2005: 118-120; and Li 2011: 46-49. 
history of these compilations, to be approved by the emperor. The terms tiaoli and shili were mainly reserved for sub-statutes to legal and administrative codes, but also occasionally used otherwise..$^{13}$

In spite of their applicability to judicial issues the sub-statutes and the zeli were not unquestionable. Derk Bodde and Clarence Morris explain that substatutes (and in analogy, also the zeli) "proved helpful for dealing with situations unthought-of by the original framers of the [Qing] Code", but "a good deal of confusion and difficulty sometimes resulted from the rather ad hoc manner in which the sub-statutes had often originated". ${ }^{14}$ To avoid these problems, the regulations were to be revised in regular intervals, at least in theory.

\section{The War Supplies and Expenditure Regulations (Junxu zeli)}

The preface of the War Supplies and Expenditure Regulations (Junxu zeli) quotes several imperial edicts concerned with the compilation of the regulations. ${ }^{15}$ It begins with a document from QL 41/4/6 (May 23rd, 1776), ${ }^{16}$ in which the Qianlong Emperor (r. 1736-1795) explains why it was necessary to compile such a set of regulations. The very first sentence includes a critical term related to geography: During the campaign against the rebel Wang Lun in Shandong (1774) ${ }^{17}$ some officials had, when submitting their final accounts, not taken into consideration that the Wang Lun affair had taken place "inside [provincial] territory" (neidi), for which different rules were valid from those for military campaigns outside provincial territory (waidi, kouwai-in contrast to "inside provincial territory", kounei). Only cost incurred as a result of campaigns beyond provincial territory was considered as "military needs" (junxu).

The basic problem was that there existed in fact no clear rules defining what costs were allowed as military expenditure (junxu) and what costs only as such

13. The word shili is also used in the same way as zeli and sometimes even just as shiyi, e.g. the regulations for the organization and funding of river conservancy work in the late 19th century, Yugong shili, or for military funding, Zengxiu chouxiang shili (1866). Tiaoli is used for the chapter headings in the Junqi zeli editions, in the sense of 'articles'.

14. Bodde and Morris (1967): 67. William C. Jones' translation of the code (1994), does not include the sub-statutes (tiaoli), and therefore does not discuss them.

15. The list of compilers is headed by Agūi (1717-1797). In Xuxiu siku quanshu, vol. 857.

16. QL 41/4/6 means the 6th day of the 4th lunar month of the 41st year of the Qianlong era (1736-1795).

17. About this incidence, see Naquin (1981). 
for 'constabulary operations' (case-related regulations for the arrest of bandits, Bu daozei shiyi)..$^{18}$ Such matters had been under discussion before, with the only outcome that the costs for 'constabulary operations' were to be brought to account within the framework of case-related regulations (shiyi), as opposed to questions concerning the cost for the deployment of troops from another province. The apparent difference between rules for 'constabulary operations' and rules for 'war supply' raises the question of how 'war' was to be defined. It seems that there were two factors determining the difference between "arresting bandits" and fighting a veritable enemy, namely troops crossing a provincial border and operating on territory 'outside of China' (which only applied to provinces located in border regions, as Shaanxi, Gansu, Sichuan and Yunnan), and troops from one province operating in another. A further criterion for the definition of what was a 'war' can be found in the weapons and military equipment regulations. Certain objects are defined there as not belonging to the basic equipment of the garrisons, but fit for being brought to account as "military needs". The expression "belongs to the items of military needs" (gui yи junxu kuan nei) mainly refers to iron tools used for pioneer work and war arrows (so-called "plum-head arrows" meizhen jian). ${ }^{19}$

From the emperor's words in the edict quoted at the beginning of the printed version of the War Supplies and Expenditure Regulations, it seems to be evident that there was a clear distinction between the rules valid for troops in one province and those of others, and therefore problems arose when military units of different provinces were involved in a campaign. Surprisingly this was not a new problem. Among the many military campaigns going on since the Qing conquest of China there were several large-scale and long-lasting ones like the suppression of the Three Feudatories (1673-1681) and the wars against the Western Mongols of Dzungaria (several campaigns during the long period between 1677 and 1757). The Qianlong Emperor planned a tighter control over the military bureaucracy throughout the empire and intended to continue earlier projects aiming at a standardization of the imperial administration. But the most important reason for the standardization of accountancy procedures to be undertaken in the late 1770s was without doubt the enormous extent of misappropriation of state funds by officials during the second Jinchuan war (1771-1776), with more than 5 million silver taels that could not be accounted for. ${ }^{20}$ Hidden cost mainly crept up in relation to expenditure for transport. The

18. Junxu zeli, prefatory memorials, fol. 1a.

19. [Bingbu] Junqi zeli, in Xuxiu siku quanshu, vol. 857, juan 6, fol. 7a. Banner troops had to provide their own war arrows, see ibid., juan 4, fol. 1a, et saepe.

20. Theobald 2013: 94. 
second Jinchuan war had cost 53 million silver taels, 38 million of which were spent for the transport of grain and another 4 million for that of equipment. ${ }^{21}$ No wonder that clear regulations had to be created defining the transport conditions. Nothing would therefore be better than to take measures for future developments, and to compare all individual provincial regulations for military expenditure (junxu shili) and "to compare and fix common rules" (heding guitiao) everyone could and had to adhere to in the future, without relying on "temporary statutes" (linshi zhouzhang). Such a common set of regulations for war supply and expenditure would "provide something to prevent [financial] disasters" (you bei wu huan).

A problematic issue was that in some provinces the so-called "baggage pay" (zhengzhuangyin, xingzhuangyin), paid out to the troops to make themselves ready for campaigning, and the so-called "stipend for appeasing the family" (anjiayin, family allowance) was paid out as a loan, while in others it was a wartime grant not to be paid back. Apart from the ethnical boundary between the Manchu Banner troops (manbing, qibing) ${ }^{22}$ and the purely Chinese Green Standard troops (lüyingbing), another one separated these 'imperial' troops from the native auxiliary troops (tubing) dispatched by allied chieftains of local tribes. To complicate things even more, the amount of the baggage pay, the daily rice rations (kouliang) and the so-called "salted-vegetable pay" (yancaiyin) differed from province to province and between the ethnic types of troops, let alone the beasts of burden their officers were allowed to get paid, the number of orderlies they could use, and the cost of military equipment and its transport. All this had to be unified in military expenditure regulations "valid universally and to be adhered to in eternity" (yongyuan tongxing zunzhao). ${ }^{23}$

The whole set of regulations was based on the 1760 "finalized regulations" of the military campaigns in the Western Territories (Xichui chengli) which were critically compared with the regulations from the "old files" of the Burma campaigns (1766-1769, Yunnan jiu'an) and those from the Jinchuan campaigns. One reason for delay were the many differing regulations in the various provinces that had dispatched troops to the war theatre. ${ }^{24}$ It would

21. Ibid., 38 .

22. On the problem of calling the Banners "Manchu", see Elliott (2001), 337-344.

23. Junxu zeli, prefatory memorials, fol. 2a.

24. Beijing, Yunnan, Sichuan, Hubei, Hunan Shaanxi, Gansu, Guizhou, and Yunnan. See Theobald 2013: 47. 
be necessary to decide whether old models would be kept intact or a "golden mean between differing rules" was found (zhuoding hezhong). ${ }^{25}$

The Ministry of Revenue had joined with the Ministries of War (bingbu) and Works (gongbu) to create a tripartite set with "unified" (tonggui huayi) regulations for war supply and expenditure. It consists of 64 articles under the jurisdiction of the Ministry of Revenue (called Hubu junxu zeli), 40 under that of the Ministry of War (Bingbu junxu zeli), and 15 were related to the Ministry of Works (Gongbu junxu zeli). The compilers explained that while some ancient rules had been retained unaltered, the figures (pay, horses, orderlies, etc.) of some were adapted to meet the present conditions throughout the empire, and were either raised or reduced. The rules concerning weapons and military equipment had not been changed at all in the new regulations. Matters of dispute had been left open to the provinces to meet the local conditions. 47 articles were newly determined. The regulations were finished on QL 50/2/9 (March 19th, 1785) and printed and bound in six volumes, with a length of 16 juan or chapters. ${ }^{26}$

The issue of 'territory' plays an important role not only for the creation of the War Supplies and Expenditure Regulations, but also with regard to the question how much to pay for troops marching to different categories of destinations. And thirdly the question of territory is also involved when it comes to troops of different ethnic origins.

The old regulations from the campaigns in the Western Territories or the Burma campaigns (the Yunnan regulations) have not survived in a compact form, but only as truncated quotations in the commentary on the War Supplies and Expenditure Regulations. The only more or less surviving regional war supply and expenditure regulations are those from the Jinchuan campaigns as part of the collection Pingding Liang Jinchuan junxu li'an, reconstructed and published by Zheng Qishan. ${ }^{27}$ In the Jinchuan collection of regulations it can be seen that in some respect the rules of the province of Sichuan, responsible for the conduct of the campaign, differed from those of Guizhou, Yunnan and Shaan-Gan (Shaanxi and Gansu).

A few examples of the War Supplies and Expenditure Regulations might serve to illustrate the method by which the compilers reconciled contradictory regulations of the earlier regulations. The reconstruction of the regulations of the second Jinchuan campaign in the Pingding Liang Jinchuan junxu li'an

25. Junxu zeli, prefatory memorials, fol. $5 \mathrm{~b}$. On the lengthy auditing process of the account of this war, see Theobald 2013: 86-96.

26. Junxu zeli, prefatory memorials, fol. 9a.

27. Zheng 1991. 
allows a direct and exemplary comparison between the regulations for baggage pay in four different regions, namely Sichuan, Shaan-Gan (the provinces responsible for the Western campaigns), Hu-Guang (i.e. Hubei and Hunan, whose troops took part in practically all great campaigns), and Yun-Gui (i.e. Yunnan and Guizhou, from where the Burma campaigns were conducted). This information adds to the commentary to the War Supplies and Expenditure Regulations, where it is only succinctly stated that all regulations "differed widely" (shen xuan shu) from province to province. ${ }^{28}$

\begin{tabular}{|c|c|c|c|c|c|}
\hline \multirow[b]{2}{*}{ rank } & \multirow{2}{*}{\begin{tabular}{|c|} 
Sichuan \\
loan, to be \\
paid back in \\
instalments \\
\end{tabular}} & \multicolumn{2}{|c|}{ Shaan-Gan } & \multirow{2}{*}{$\begin{array}{l}\text { Hu-Guang } \\
\text { loan, to be } \\
\text { paid back }\end{array}$} & \multirow{2}{*}{$\begin{array}{c}\text { Yun-Gui } \\
\text { gratification }\end{array}$} \\
\hline & & gratification & $\begin{array}{l}\text { loan, to be } \\
\text { paid back }\end{array}$ & & \\
\hline $\begin{array}{l}\text { provincial } \\
\text { commanders- } \\
\text { in-chief }(t i d u)\end{array}$ & 1,000 & 2 years salary & 350 & & \\
\hline $\begin{array}{l}\text { brigade generals } \\
\text { (zongbing) }\end{array}$ & 1,000 & $"$ & 250 & 500 & \\
\hline colonels (fujiang) & 500 & $"$ & 200 & 300 & 60 \\
\hline $\begin{array}{l}\text { lieutenant- } \\
\text { colonels } \\
\text { (canjiang) }\end{array}$ & 150 & $"$ & 150 & 250 & 60 \\
\hline majors (youji) & 150 & $"$ & 150 & 200 & 40 \\
\hline first captains (dusi) & 100 & $"$ & 100 & 100 & 40 \\
\hline $\begin{array}{l}\text { second captains } \\
\text { (shoubei) }\end{array}$ & 100 & $"$ & 100 & 80 & 30 \\
\hline $\begin{array}{l}\text { lieutenants } \\
\text { (qianzong) and } \\
\text { second lieutenants } \\
\text { (bazong) }\end{array}$ & 40 & $"$ & 40 & 50 & 15 \\
\hline sergeants (waiwei) & 12 & $"$ & 12 & 40 & 8 \\
\hline $\begin{array}{l}\text { common troops } \\
\text { (bingding)* }\end{array}$ & 5 & 8 & 4 & 19.5 & 1.3 \\
\hline$*$ average of: & $\begin{array}{l}\text { cavalry } 6 \\
\text { infantry } 4\end{array}$ & $\begin{array}{l}\text { cavalry } 10 \\
\text { infantry } 6\end{array}$ & cavalry only & $\begin{array}{l}\text { cavalry } 24 \\
\text { infantry } 18 \\
\text { guard } 15 \\
\end{array}$ & \\
\hline
\end{tabular}

Source: Pingding Liang Jinchuan junxu li'an, juan 2, fol. 39a-40b.

Table 1. Baggage pay for Green Standard troops

from different provinces (before 1785), in taels

28. Junxu zeli: Hubu junxu zeli, juan 1, fol. 3b. 
Another example for differing regulations in the provinces can be seen in the question of the salted-vegetable money, paid out on a monthly basis and to be used to buy food with, and the daily rice rations. Part of the regulations in the Jinchuan war (Sichuan junxu or Sichuan an) followed older precedents from Shaanxi and Gansu for the Western campaigns (Xichui tiaoli, Xichui an).

\begin{tabular}{|c|c|c|c|c|c|c|}
\hline \multirow[t]{2}{*}{ rank } & \multicolumn{2}{|c|}{$\begin{array}{l}\text { salted-vegetable pay (in } \\
\text { taels) per month in }\end{array}$} & \multirow{2}{*}{$\begin{array}{l}\text { salted } \\
\text { vegetable } \\
\text { pay (in } \\
\text { taels) per } \\
\text { month in } \\
\text { Junxu zeli }\end{array}$} & \multicolumn{2}{|c|}{ orderlies in } & \multirow{2}{*}{$\begin{array}{l}\text { orderlies } \\
\text { in Junxu } \\
\text { zeli }\end{array}$} \\
\hline & Sichuan & Shaan-Gan & & Sichuan & $\begin{array}{l}\text { Shaan- } \\
\text { Gan }\end{array}$ & \\
\hline $\begin{array}{l}\text { provincial } \\
\text { commanders- } \\
\text { in-chief }(t i d u)\end{array}$ & 15 & 12 & 12 & 32 & 24 & 24 \\
\hline $\begin{array}{l}\text { brigade generals } \\
\text { (zongbing) }\end{array}$ & 15 & 9 & 9 & 24 & 16 & 16 \\
\hline colonels (fujiang) & 7.2 & 7.2 & 7.2 & 16 & 10 & 12 \\
\hline $\begin{array}{l}\text { lieutenant-colonels } \\
\text { (canjiang) }\end{array}$ & 4.2 & 4.2 & 4.2 & 10 & 8 & 10 \\
\hline majors (youji) & 4.2 & 4.2 & 4.2 & 8 & 8 & 8 \\
\hline first captains (dusi) & 4.2 & 2.5 & 3 & $8(6) c)$ & 6 & 6 \\
\hline $\begin{array}{l}\text { second captains } \\
\text { (shoubei) }\end{array}$ & 2.4 & 2.5 & 2.4 & 6 & 6 & 6 \\
\hline $\begin{array}{l}\text { lieutenants (qian- } \\
\text { zong) }\end{array}$ & 2.4 & 1.8 & 2 & 3 & 3 & 3 \\
\hline $\begin{array}{l}\text { second lieutenants } \\
\text { (bazong) }\end{array}$ & $1.2(?)$ & $?$ & 1.5 & 3 & $?$ & 3 \\
\hline sergeants (waiwei) & $0.9(1.3) \mathrm{c})$ & $?$ & 1.5 & [1] & $?$ & 2 \\
\hline $\begin{array}{l}\text { common troops } \\
\text { (bingding) }\end{array}$ & $\begin{array}{c}0.9, \text { later } \\
1.3\end{array}$ & $?$ & $0.9+0.4 \mathrm{~b})$ & $0.3 \mathrm{a})$ & $?$ & $0.3 \mathrm{a})$ \\
\hline $\begin{array}{l}\text { orderlies (genyi) of } \\
\text { officers }\end{array}$ & 0 & $?$ & 0 & 0 & $?$ & 0 \\
\hline orderlies of privates & 0.5 & $?$ & 0.5 & 0 & $?$ & 0 \\
\hline
\end{tabular}

Sources: Junxu zeli : Hubu junxu zeli, juan 3, fol. 3a-4b; Pingding Liang Jinchuan junxu li'an, juan 2, fol. 27b-29a.

a) Ten soldiers were waited on by three orderlies.

b) Common soldiers were given an additional monthly pay of 0.4 tael when entering foreign territory.

c) The commentary to the Junxu zeli in some cases cites figures (in brackets) which differ from the 'original' precedents in the Sichuan files.

Table 2. Money for victuals, daily rice rations and orderlies for Green Standard troops from Sichuan (before 1785 and after) 
The data in Table 2 demonstrate that there were substantial differences, especially in the higher echelons of the command structure. One purpose of the War Supplies and Expenditure Regulations was to reduce cost, for which these data give evidence. In some instances the compilers of the War Supplies and Expenditure Regulations calculated a mean value out of two figures taken from different regulations. The original number of orderlies for colonels (fujiang) was 16 in Sichuan, and 10 in Shaan-Gan 10. The new number was 12. In others, disproportions were adjusted, like the higher pay for victuals given to sergeants, compared to that for second lieutenants.

In spite of its character as a collection of administrative regulations valid all over the country, there were still local differences, mainly in the cost for objects used to produce equipment and weaponry. The accounting of objects like cannonballs (brass or iron), clothing, sulphur, nitre, charcoal, timber (for boats), or the wide array of small arms and polearms, was permitted according to the regulations on prices and wages (Wuliao jiazhi zeli) of the province in question. ${ }^{29}$ In quite a few instances the prices of goods - and not only those for grain-rose because of the high demand in war time, for instance, that of nitre. ${ }^{30}$ The Ministry of Revenue, responsible for all state expenditure, accepted such fluctuations because basic material as sulphur, nitre or lead was not available in all provinces and districts.

Other rules involving the issue of space are found in regulations concerning the daily rations of troops. ${ }^{31}$ From the day they left the garrison, they were granted a daily rice ration, and from the time they left their respective home province (li gai sheng) or provincial territory (chu kou or chu biankou), they were additionally paid out the salted-vegetable money (in case of common troops: 0.4 tael per month). When returning home after the end of the campaign, the procedure was reversed: As soon as they set foot on provincial territory (or their home province), payment of the salted-vegetable money was discontinued. The same procedure was followed for all types of troops, as well as for civilian officials serving in the logistics.

29. Christine Moll-Murata has written about labour pay in the Wujiao jiazhi zeli, see her "Remarks on Wuliao jiazhi zeli, the Price and Wage Regulations in Public Construction, issued by the Ministry of Public Works (1769-1796)."

30. Junxu zeli: Gongbu junxu zeli, juan 1, fol. 2a.

31. Junxu zeli: Hubu junxu zeli, juan 3, fol. 3a-4b). 
Space and Place in Administrative Military Regulations of Qing China

\section{The Weapons and Military Equipment Regulations (Junqi zeli)}

The history of the Weapons and Military Equipment Regulations is somewhat more complex..$^{32}$ It can be seen that the production and procurement of weapons was also a question in the third part of the War Supplies and Expenditure Regulations (called Gongbu junxu zeli), and many details were left open to local conditions. This is also the case in the Weapons and Military Equipment Regulations and makes them all the more interesting concerning the issue of the relation between law and space. There were two of them, one compiled by the Ministry of War ([Bingbu] Junqi zeli) and regulating the maintenance of objects in all garrisons throughout the empire, and one compiled by the Ministry of Works (Gongbu junqi zeli), focusing on the production of weapons and equipment. ${ }^{33}$ The enormous diversity of equipment required a higher standardization of maintenance work, yet from the beginning the compilers of the regulations took into consideration the "diversity of the local conditions of each province" (ge sheng qingxing) influencing the repairing and maintenance periods and the lifespan of material. ${ }^{34}$ "Local conditions" meant the fertility of the soil (difang feiji), the laboriousness of the troops (bingding laoyi), and the climate (diqi zhi zaoshi). ${ }^{35}$ The new, empire-wide regulations therefore kept to the existing "old regulations" (jiuli) and the "established regulations of each garrison" (benying dingli) and respected them to such an extent that it was not desired that the slight differences between individual garrisons might be quoted as precedents for changes in other garrisons or provinces. ${ }^{36}$ The resulting regulations thus aimed at standardization with "variations wherever considered appropriate" (zhuoliang biantong). Since local conditions differed, only the respect for such variance would be "profitable" (yi zi li yong) ${ }^{37}$

The most widespread edition of the Weapons and Military Equipment Regulations (of the Ministry of War) is that of 1816,38 compiled under the

32. A Chinese introduction was presented by You 2005: 307-324.

33. To distinguish the latter from the regulations of the Ministry of War, they are called Gongbu junqi zeli (while the designation Bingbu junqi zeli is not common-they are just called Junqi zeli).

34. (QL 56) [Bingbu] Junqi zeli, juan 1, prefatory memorials, fol. 1a.

35. (JQ 9) [Bingbu] Junqi zeli, juan 1, prefatory memorials, [fol.3a].

36. Ibid.

37. (JQ 21) [Bingbu] Junqi zeli, juan 1, prefatory memorials, fol. 1a.

38. Finalization of the Chinese and Manchu version on JQ 20/12/15 (January 13th, 1816). The Manchu translations seemed to have been a complex matter and required four years of work, until both versions were published and distributed to the provinces, see (JQ 21) [Bingbu] Junqi zeli, prefatory memorials, fol. 5a, 7a. The compilation of the 
supervision of Dong Gao (1740-1818), with a length of 24 juan. The oldest compilation of this type was begun as early as 1771 and finished in 1791 (not divided into juan), followed by a revision in 1805 (32 juan). ${ }^{39}$ The compilation of a new edition was ordered as early as $1801^{40}$ but was delayed for more than ten years before the thorough investigation was really put into operation. The highest local military commanders in charge were ordered to have reports collected from each garrison providing information about how many and what types of tools were kept, and to add descriptions of their specifications, along with drawings (the latter are unfortunately not included in the printed version of the regulations). ${ }^{41}$

The resulting book details types, properties and maintenance periods (xiuzhi nianxian) of weapons and equipment in the possession of Banner and Green Standard garrisons. The [Bingbu] Junqi zeli shows what objects were used in which province. With the help of it a kind of virtual map can be drawn indicating the local use of certain weapons or tools. Horse saddles ( $m a^{\prime}$ an), for instance, are only mentioned as equipment of the Firearms Brigade (huoqiying) in the capital, some individual garrisons in the colonial territory in the west and such in the provinces, but in all garrisons in Yunnan (as "monkey-head saddles", hu'ertou ma'an). Transport saddles (ta'an, duo'an) ${ }^{42}$ are exclusively listed in Hunan, Sichuan and provincial Banner Garrisons. Saddles for transporting light cannon (duopao'an, in Sichuan and Hunan called pao'an) were only used in the western regions in Turkestan (modern Xinjiang), Shaanxi, Gansu, Sichuan and Hunan. In the western regions cannons were carried by camels (as "camel guns", luotuo pao). Boots called xue were only known in Zhejiang, while the term xie was used otherwise, except (or only rarely) in Hunan, Guangdong, Fujian and Zhili. Oil cloth (youbu) was uncommon in Shandong, Henan, Sichuan, Guangdong, Guangxi, Shaanxi and Gansu. Surprisingly this distribution does not express climatic conditions, while the use of camels is surely restricted to the dry climate in the north and northwest of China. Targets for training archery (jianba), artillery (paoba) or musket shooting (qiangba) are not found in Zhili (today's Hebei) and rarely in Jiangnan (today's Jiangsu). Iron saws (tieju) as equipment of the pioneers were not listed in garrisons of

regulations was finished as early as QL 19/12/12 (January 21st, 1815). It is part of the series Хuxiu siku quanshu, vol. 857. The 1791 and 1805 editions are found in the series Gugong zhenben congkan 2000: vol. 293.

39. (QL 56) [Bingbu] Junqi zeli, juan 1, prefatory memorials, fol. 3b.

40. (QL 56) [Bingbu] Junqi zeli, juan 1, prefatory memorials, fol. 1a.

41. (QL 56) [Bingbu] Junqi zeli, juan 1, prefatory memorials, fol. $1 \mathrm{~b}$.

42. The term ta'an was more often used by the Banners and in Sichuan, duo'an in Hunan. 


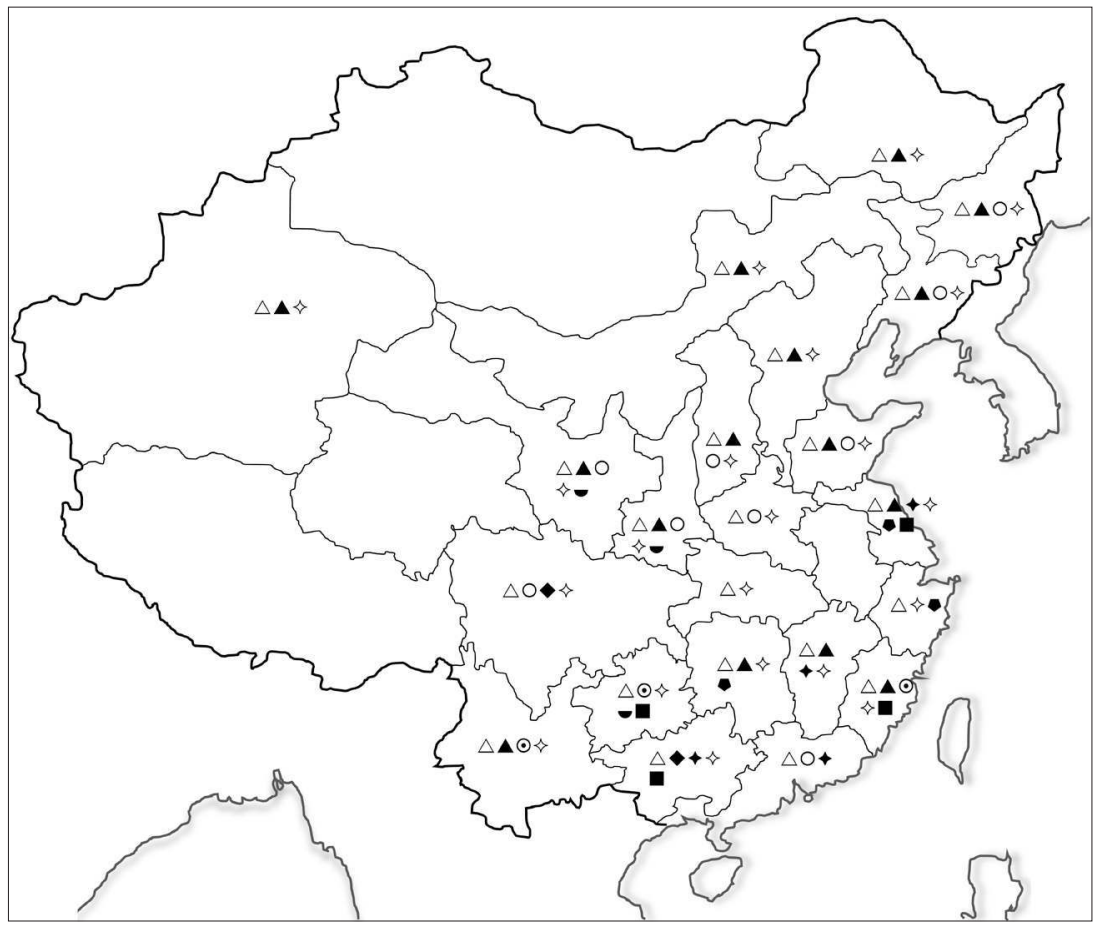

Map 1. Distribution of selected items in provincial garrisons

Note: because not all garrisons can be shown in the map the use of weapons and implements is indicated per province, symbols representing use in the majority of garrisons in the province in case, while occasional use is ignored.

$\triangle$ single-lined tents (dan zhangfang), $\boldsymbol{\Delta}$ double-lined tents (jia zhangfang), $\bigcirc$ cotton helmets (miangai), $\odot$ leather helmets (pigai), $\downarrow$ leather powder flasks ( pi hulu), $\diamond$ flasks for black powder (huoyao hulu) and for priming powder (hongyao hulu), - powder baskets (huoyao lou), bullet bags (qianzi dai), $\mathbf{\square}$ bullet buckets (qianzi tong)

Map based on Tan Qixiang, Zhongguo lishi ditu ji : vol. 8, map 5-6.

Zhili, Jiangnan, Shandong, Henan, Guangdong, Guangxi, Hunan, and parts of Jiangxi, Zhejiang, Shaanxi, Gansu and Guizhou. The standard weapon of all garrisons was the so-called "bird musket" (niaoqiang), called thus because of the 'pecking' movement of the cock when slashing down the fuse on the pan. Only very few garrisons were not equipped with it, but the bow was likewise an indispensable weapon for all types of troops all over the empire, barring most naval garrisons. Of the many types of guns some were quite widespread, like the "gun of far-reaching authority" (weiyuan pao, with concentrations 
in the northwestern colonial garrisons, Shandong, Shanxi, Shaanxi, Gansu, Sichuan, and Guangxi), but others were only in local use, like the "victorious gun" (desheng pao) popular in Yunnan and rarely found elsewhere. Some other examples can be found in Map 1.

One novelty of the regulations was that for each object a kind of 'lifespan' was defined. Very typical is that it was allowed to bring to account cost for repairing or 'overhauling' them after half the lifespan, and finally to fully amortize cost. The lifespan of a musket, for instance, was defined as being 40 years, with a first repair allowed after 20 years. Banners and flags were to be used for 30 years, powder flasks for 25 years, saddles for 20 , and cannon equipment like mounts or linstocks for 5 years, with a first repair after 3 years. These rules seem to have been unified for the whole empire, and nowhere these figures deviate, in spite of the abundance of types of weapons and equipment.

The itemization of weapons for each garrison follows a set pattern. The first part lists objects with their 'lifespan', the second only those "taken along when campaigning" (xing jun xiu dai) and cleared as "war expenditure" (junxu), the third itemizes objects to be produced (and paid) by the individual garrisons (ying zhong zi bei; as "hard bows" difficult to pull, yinggong, or targets for training), the fourth inventories those to be "provided by the troops themselves" (bingding zi bei), and lastly come those whose "maintenance was to be discontinued", while the tools and weapons themselves continued to be "put into storage" (and used, tingxiu cunzhu). This concerned mainly the apparently outdated iron armour with helmets and cuirasses or breastplates (tiekui tiejia) and certain types of cannon. This decision aimed at both cutting cost and standardizing types.

Even in this highly standardized pattern, differences between the garrisons within one province can be found. In some garrisons of Shandong, for instance, the maintenance of "double swords" (shuangdao) and "single swords" (dandao) was declared to be discontinued, in others only that of the double swords. In some garrisons the troops were responsible for their own quivers, boots, jackets, and trousers, in others they had additionally to have ready bluegreen clothes (qingyi, qingmao, qingku), as well as "war belts" (zhanyao), fuses, leather pouches and brass powder flasks (tong yaoguan). While some garrisons had to produce and keep in order leather bags and wooden boards for announcing the watches (gengqian), others were exempt, whereas yet others had to prepare a wide array of musical instruments (trumpets, drums, horns and gongs), used for a kind of military band, or for signalling in battle. ${ }^{43}$

43. (JQ 21) [Bingbu] Junqi zeli, juan 11, fol. 3a-8b. 
In the same decade of the Jiaqing reign (1796-1820) the Ministry of Works compiled a set of weapons and equipment regulations in which production processes and production prices (material and labour) were regulated. It was compiled under the direction of Liu Quanzhi (1739-1818), finished in 1811 and has a length of 60 juan.

The Weapons and Military Equipment Regulations (of the Ministry of War) had three aims, namely to reduce cost and to prevent waste and abuse, to ensure a proper maintenance of the objects in order to have them in good condition in case of war, and standardize production methods, the type of materials, as well as material and labour cost (zuofa, gongliao [...] jiazhi) for the production of weapons and other objects. ${ }^{44}$ Yet there was no empire-wide unification of these issues. The regulations therefore list all provinces and even all garrisons throughout Qing China, and describe the specifications of a large amount of weapons and military equipment on a garrison level, and not on a 'national' one.

The Weapons and Military Equipment Regulations of the Ministry of Works from 1811 begins with a request of the Ministry from JQ 13/4/7 (May 2nd, 1808) to revise the original regulations from 1798 (begun in 1793). New local information had to be incorporated (the northeastern provinces and Xinjiang), and details of the production methods and cost of weapons already included in the regulations of the Ministry of War that was under compilation. It was suggested to send out special staff to all garrisons to inspect the terminology and specifications of objects there (junqi mingmu), and so create a virtual 'inventory' of all weapons used by the Qing military. The result was a first draft of regulations on the manufacturing methods of weapons and equipment (Junqi zuofa zeli). ${ }^{45}$ The final regulations were to be brought up to date every ten years. ${ }^{46}$

A particular problem was the varying terminology for objects in different places and that weapons and equipment were produced with different materials in different quality and according to varying specifications. The provincial governors were requested to supply information on the garrisons in their territory, with specifications on all objects, along with drawings ${ }^{47}$ These were

44. Gongbu junqi zeli, juan 1, prefatory memorials, fol. 1a.

45. Gongbu junqi zeli, juan 1, prefatory memorials, fol. 2a.

46. Gongbu junqi zeli, juan 1, prefatory memorials, fol. 1a. The effect of the revision can be seen in the arrangement of chapters, where supplements are inserted in-between.

47. Gongbu junqi zeli, juan 1, prefatory memorials, fol. 5a. Unlike the Da-Qing huidian and the Liqi tushi, which includes many illustrations, which the weapons and equipment regulations do not retain. 
subsequently more or less standardized in order to ensure a more uniform supply for all garrisons. The tremendous task was only finished on JQ 17/9/12 (October 16th, 1812), when the emperor gave his imprimatur to the regulations, so that both, that of the Ministry of Works and that of the Ministry of War, could be sent as reference guides to the garrisons throughout the empire. ${ }^{48}$

The authors of the regulations tried to standardize the most basic properties of weapons. Concerning cannons, for instance, the regulations of the Ministry of Works specify the raw material and components for different types of iron. For 100 jin (c. $500 \mathrm{~g}$ ) of "refined iron" (shutie), for instance, 400 jin of crude iron (huangtie) were used, one cover for the melting pot (gaihuo), 2 jin of steel (gang) and 2 jin of oil. For melting 100 jin of crude iron, 20 jin and 8 liang of charcoal (mutan) were used and 700 jin of coal (meitan). For processing 100 jin of iron, 1 "work unit" (yi gong, i.e. the work of one day) of "iron labour" (tiejiang) was necessary, 0.5 unit of "wringing labour" (ningjiang), and 0.2 unit of drilling work (zaojiang), with 5 men (zhuangfu) performing one work unit. ${ }^{49}$ Similar requirements are presented for gun barrels made of pig iron (shengtie) and brass (shengtong). The prices of iron and brass differed from province to province, but the regulations fixed how much the government would be willing to pay. An example from Gongbu junqi zeli, juan 43, fol. 8a9b; juan 44, fol. 8a-10a; juan 45, fol. 9a-10b; juan 46, fol. 8a-10a, showing differences in the prices of brass (in tael):

\begin{tabular}{|l|c|c|c|c|}
\hline & Zhili & Jiangsu & Anhui & Jiangxi \\
\hline raw brass (shengtong), per jin & 0.18 & 0.18 & 0.18 & 0.16 \\
\hline red refined brass (hong shutong), per jin & 0.23 & 0.22 & 0.22 & 0.2 \\
\hline yellow refined brass (huang shutong), per jin & 0.2 & 0.2 & 0.2 & 0.18 \\
\hline
\end{tabular}

Table 3. Prices of brass (in tael)

The decision on size, calibre, decoration and so on was left to the individual garrisons. This is very surprising and needs further research, but this fact is the most important hint that the regulations aimed not at the unification of weapons and objects, but at cost control.

As can be seen from this analysis, not only did some of the prices differ from province to province, but the equipment of the garrisons was not identical, either. While basic materials as metals of different types were found

48. Gongbu junqi zeli, juan 1, prefatory memorials, fol. 9b.

49. Gongbu junqi zeli, juan 25, fol. 5b-7a. 
everywhere and were allowed to be brought to account at the same price (with slight deviations), the range of tools and implements varied considerably. This was due to the local conditions and was not altered by the compilation team of the regulations. The new regulations added as much variety as possible, thus diversifying the range of objects instead of reducing their complexity. It was attempted to retain as many of the local usages as possible, but to fix their production cost within the bounds of possibility.

\section{Conclusions}

The War Supplies and Expenditure Regulations, written in order to cut cost for military campaigns by enacting empire-wide rules for allowances and for accounting, includes several issues related to the topic of 'space'. One isfound in an edict quoted in the introductory part-a definition of 'war', in contrast to 'constabulary actions': 'War' involved troops of several provinces or caused troops to pass provincial or 'national' borders. Only under such conditions it was allowed to settle cost as "war expenditure". The regulations were a real unification of differing guidelines for supplying campaigning armies in various parts of the empire and beyond. The compilers compared earlier regulations and fixed in detail reasonable amounts of pay, numbers of horses, orderlies, and so on. The regulations discerned between elite troops from northeastern China, the Banner garrisons, Green Standard garrisons, and Mongolian allies and native auxiliaries from southwest China. It made also spatial distinctions in the provisioning of troops. When marching on territory outside the home province or outside the borders of 'China', troops were granted more provisions or a higher pay to buy them with. A province did not have to pay for troops from other provinces, and the additional pay for food granted when marching through neighbouring provinces was to ensure that the home province was able to feed its troops properly on 'foreign territory'.

The two Weapons and Military Equipment Regulations standardized the tools used in all garrisons of the empire, but allowed a very great measure of autonomy. While the number of types was somewhat reduced and the costly maintenance periods fixed, the specifications of material and the price the government was willing to pay for production remained subject to local conditions. It is therefore out of the question to talk of a thorough unification of standards. The autonomy of provinces and individual garrisons in the use of specific weapons and equipment was accepted, and even promoted: The prefatory memorials of the revised regulations explicitly state that the regulations were compiled in order to include types of equipment and weaponry 
not found in earlier versions. ${ }^{50}$ While the Weapons and Military Equipment Regulations (of the Ministry of War) fixed the 'amortisation cost' (the repair and replacement of old weapons and equipment) and determined who shared what expenditure (individual soldiers, the garrisons, or the Ministry of Revenue during war time), the Weapons and Military Equipment Regulations of the Ministry of Works created a ceiling to production cost. The unification of armament was not an aim of these two sets of regulations.

You Zhanhong in his article on the Weapons and Military Equipment Regulations blames the Qing government that "by insisting on the unification of standards [fagui de tongyi] and the saving of expenses [the] Junqi zeli [regulations] to some extent impeded the development of military technology".51 He brings forward two arguments, namely the aim of the regulations to curtail expenditure by defining what objects garrisons were to use and how much these should cost, and second, that standards were set throughout all provinces which integrated outdated weaponry into the arsenal. Ancient types of cannon were not taken out of service, but only their production and maintenance discontinued. The outdated guns continued to be used "without a phase-out [management]" (wu yong ding xian), with fatal consequences during the First Anglo-Chinese War (1839-1842). As has been shown, there was indeed no real "unification of standards" in the sense of norms valid for the whole empire. Instead, great respect for local autonomy in the use of certain types of weapons and equipment prevailed, making it impossible to rely on standards like firepower when it came to the planning of a campaign. A third problem of the Chinese military was that the diversity of weaponry was never again thought about by the central government and types and specifications not any more discussed after the promulgation of the regulations in 1816. The compilers of the regulations had recommended a revision of the regulations every ten years. Yet this "spirit of flexibility" 52 fell asleep after the Jiaqing reign and brought about the 'freezing' of the inventory of the Qing arsenals.

50. Gongbu junqi zeli, juan 1, prefatory memorials, fol. 1b-2a.

51. You 2005: 307, Chinese version on 323-324.

52. In how far the administration of the Daoguang Emperor (r. 1820-1850) is to be blamed for the abandoning of law revision is discussed in Metzger 1973: 82-83. 
Space and Place in Administrative Military Regulations of Qing China

\section{BIBLIOGRAPHY}

AMELUnG, Iwo (2005). "Preliminary Observations on 'Regulations and Precedents for River Works' (Hegong zeli) during the Qing Dynasty.” In Chinese Handicraft Regulations of the Qing Dynasty: Theory and Application, edited by Christine Moll-MuratA, Song Jianze, and Hans Ulrich VoGEL. München, Iudicium: 285305.

BoDDE, Derk and MoRRIS, Clarence (1967). Law in Imperial China: Exemplified by 190 Ch'ing Dynasty Cases. Cambridge (MA): Harvard University Press.

ElliotT, Mark C. (2001). The Manchu Way: The Eight Banners and Ethnic Identity in Late Imperial China. Stanford: Stanford University Press.

(Qinding) Gongbu junqi zeli (欽定) 工部軍器則例. [Unpublished photomechanical reproduction of the 1811 edition.]

HEAD, John W. and WANG, Yanping (2005). Law Codes in Dynastic China: A Synopsis of Chinese Legal History in the Thirty Centuries from Zhou to Qing. Durham (NC): Carolina Academic Press.

JONES, William C. (1994). The Great Qing Code. Oxford: Clarendon.

(Qinding) Junqi zeli (欽定) 軍器則例. Series Xuxiu siku quanshu 續修四庫全書, vol. 857. Shanghai: Shanghai guji chubanshe, 2002.

(Qinding) Junqi zeli (欽定) 軍器則例 [1816 edition]. Series Xuxiu siku quanshu, vol. 857. Shanghai: Shanghai guji chubanshe, 2002. [Accessed April 16th, 2015. https://archive.org/search.php?query=欽定軍器則例]

(Qinding) Junqi zeli (欽定) 軍器則例 [1791 and 1805 editions]. Series Gugong zhenben congkan 故宮珍本叢刊, edited by Gugong bowu yuan 故宮博物院, vol. 293. Haikou: Hainan chubanshe, 2000.

(Qinding) Junxu zeli (欽定) 軍需則例. Series Xuxiu siku quanshu 續修四庫全書, vol. 857. Shanghai: Shanghai guji chubanshe, 2002. [Accessed April 16th, 2015. https://archive.org/search.php?query=欽定戶部軍需則例 and https://archive. org/details/02089768.cn (i.e. 欽定兵工部軍需則例)]

LI, Liuwen 李留文 (2011). “Qingdai zeli bianzuan yanjiu 清朝则例编纂研究.” Dang'anxue tongxun 档案学通讯, 1: 46-49.

LI, Liuwen 李留文 (2005). “Qingdai zeli chutan 清代则例初探.” Guangxu shehui kexue 广西社会科学, 9: 118-120.

LI, Liuwen 李留文 (2006). “Qingdai zeli de tedian ji qi liyong 清代则例的特点及其 利用.” Guizhou shehui kexue 贵州社会科学, 5: 160-161, 165.

LI, Yongzhen 李永贞 (2010). “Chuyi Qingdai zeli de xingzhi he fenlei 刍议清代则例 的性质和分类.” Faxue zazhi 法学杂志, 10: 73-75.

Metzger, Thomas A. (1973). The Internal Organization of Ch'ing Bureaucracy: Legal, Normative and Communication Aspects. Cambridge (MA): Harvard University Press.

Moll-MuratA, Christine (2001). "New Editions of Qing Dynasty Handicraft Regulations and Precedents (Jiangzuo zeli): Definition and Main Characteristics of the Genre." Revue Bibliographique de Sinologie, XIX: 255-271. 
Moll-MuratA, Christine. "Remarks on Wuliao jiazhi zeli, the Price and Wage Regulations in Public Construction, issued by the Ministry of Public Works (1769-1796)." [Accessed April 16th, 2015. http://www.iisg.nl/hpw/wuliao.pdf]

NAQUIN, Susan (1981). Shantung Rebellion: The Wang Lun Uprising of 1774. New Haven: Yale University Press.

TANII, Yōko 谷井陽子 (1995). “Shindai sokurei shōrei kō 清代則例省例考.” Tōho gakuho, 67: 137-239.

THEOBALD, Ulrich (2013). War Finance and Logistics in Late Imperial China: A Study of the Second Jinchuan Campaign (1771-1776). Leiden: Brill.

WANG, Zhiqiang 王志強 (2001). "Lun Qingdai de difang fagui: Yi Qingdai shengli wei zhongxin 论清代的地方法规：以请代省例为中心.” Zhongguo xueshu 中国学 術, 3: 120-150.

WiLKInSON, Endymion (2012). Chinese History: A New Manual. Cambridge (MA)/ London: Harvard University Asia Center.

XIA, Yongfu 夏永孚 (1991). “Qingchao buyuan zeli de bianzhi ji qi zuoyong shi shenme? 清朝部院則例的編制及其作用是甚麼.” In Zhongguo gudai falü sanbai $t i$ 中國古代法律三百題, edited by CHEN Pengsheng 陳鵬生. Shanghai, Shanghai guji chubanshe: 98-100.

YOU, Zhanhong 游戰洪 (2005). “Lun Junqi zeli 論軍器則例/A Study of Regulations and Precedents on Weapons and Military Equipment." In Chinese Handicraft Regulations of the Qing Dynasty: Theory and Application, edited by Christine Moll-MuratA, Song Jianze, and Hans Ulrich VoGEL. München, Iudicium: 307324.

ZHENG, Qishan 鄭棲山 (1991). Pingding Liang Jinchuan junxu li'an 平定兩金川軍需 例案. Series Xizangxue Hanwen wenxian huike 西藏學漢文文獻彙刻, edited by Xizang shehui kexue yuan 西藏社會科學院, vol. 2. Beijing: Quanguo tushuguan wenxian suowei fuzhi zhongxin.

\section{GLOSSARY}

Agūi 阿桂

anjiayin 安家銀

bazong 把總

benying dingli 本營定例

bing $b u$ 兵部

[Bingbu] junqi zeli 兵部軍器則例

bingding 兵丁

bingding laoyi 兵丁勞逸

bingding zi bei 兵丁自備

Bu daozei shiyi 捕盗賊事宜

canjiang 參將 
Caoyun quanshu 漕運全書

chengli 成例

chu biankou 出邊

chu kou 出口

Da-Qing huidian 大清會典

Da-Qing huidianshili 大清會典事例

Da-Qing lüli 大清律例

Da-Qing tongli 大清通禮

dan zhangfang 單帳房

dandao 單刀

desheng pao 得勝歪

difang feiji 地方肥癐

dingli 定例

diqi zhi zaoshi 地氣之燥濕

Dong Gao 董誥

duo'an 䭾鞍

duopao'an 䭾碼鞍

dusi 都司

fagui de tongyi 法規的統一

fujiang 副將

Fuyi quanshu 賦役全書

gaihuo 蓋火

gang 綱 (net structure)

gang 鋼 (steel)

ge sheng qingxing 各省情形

gengqian 更籤

gongbu 工部

Gongbu junqi zeli 工部軍器則例

Gongbu junxu zeli 工部軍需則例

Gongbu zeli 工部則例

gongliao 工料

gui yu junxu kuan nei 歸於軍需欵內

heding guitiao 核定規條

Hegong zeli 河工則例

hong shutong 紅熟銅

hongyao hulu 烘藥葫蘆

$\mathrm{Hu}$-Guang 湖廣

huang shutong 黃熟銅

huangtie 荒鐵

Hubu guzhu zeli 戶部鼓鑄則例 


\section{Ulrich Theobald}

Hubu junxu zeli 戶部軍需則例

Hubu zeli 戶部則例

hu'ertou ma'an 猴兒頭馬鞍

Hunan sheng li 湖南省例

huoqiying 火器營

huoyao hulu 火藥葫蘆

huoyao lou 火藥笽

jia zhangfang 夾帳房

jianba 箭靶

Jiangzuo zeli 匠做則例

jiazhi 價值

Jinchuan 金川

Jinzheng jiyao 育政輯要

jiuli 舊例

junqi mingmu 軍器名目

Junqi zuofa zeli 軍器做法則例

junxu 軍需

junxu shili 軍需事例

Junxu zeli 軍需則例

kouliang 口糧

kounei $\square$ 內

kouwai $\square$ 外

$l i$ 例

li gai sheng 離該省

Libu quanxuan zeli 吏部銓選則例

Libu zeli 吏部則例

Lifanyuan zeli 理藩院則例

linshi zhouzhang 臨事周章

Liqi tushi 禮器圖式

Liu Quanzhi 劉權之

Liubu chufen zeli 六部處分則例

luotuo pao 駱駝䂭

lii 律

lïyingbing 綠營兵

manbing 滿兵

meizhen jian 梅針箭

ma'an 馬鞍

meitan 煤炭

miangai 棉盔

$m u$ 目 
Space and Place in Administrative Military Regulations of Qing China

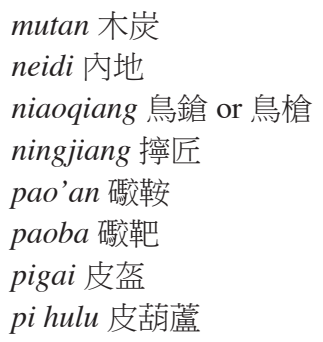

Pingding Liang Jinchuan junxu li'an 平定兩金川軍需例案

qiangba 鎗靶

qianzi dai 鉛子袋

qianzi tong 鉛子桶

qianzong 千總

qibing 旗兵

qingku 靑褲

qingmao 靑帽

qingyi 靑衣

shen xuan shu 甚懸殊

shengli 省例

shengtie 生鐵

shengtong 生銅

shili 事例

shiyi 事宜

shoubei 守備

shuangdao 隻刀

shutie 熟鐵

Sichuan an 四川案

ta'an 䭾鞍

tiaoli 條例

tidu 提督

tiejiang 鐵匠

tieju 鐵鋸

tiekui tiejia 鐵盔鐵甲

tingxiu cunzhu 停修存貯

tonggui huayi 統歸畫一

tong yaoguan 銅藥管

Tongzheng bianlan 銅政便覽

tubing 土兵

waidi 外地

waiwei 外委 


\section{Ulrich Theobald}

Wang Lun 王倫

weiyuan pao 威遠碼

Wuliao jiazhi zeli 物料價值則例

wu yong ding xian 冊庸定限

Xianxing zeli 現行則例

Xichui an 西陣案

Xichui chengli 西陲成例

$x i e$ 鞋

xing jun xiu dai 行軍攜帶

Xingbu xianxing zeli 刑部現行則例

xingzhuangyin 行裝銀

xiuzhi nianxian 修製年限

$x$ u 靴

Xuezheng quanshu 學政全書

yancaiyin 鹽菜銀

yi gong 一工

yi zi li yong 以資利用

ying zhong zi bei 營中自備

yinggong 硬弓

yongyuan tongxing zunzhao 永遠通行遵照

you bei wu huan 有備無患

youbu 油布

youji 游擊

Yugong shili 豫工事例

Yunnan jiu'an 雲南舊案

zaojiang 贅匠

$z e l i$ 則例

Zengxiu chouxiang shili 增修籌餉事例

zhangcheng 章程

zhanyao 戰腰

Zheng Qishan 鄭棲山

zhengzhuangyin 整裝銀

Zhongshu zhengkao 中樞政考

zhouzhang 周章

zhuangfu 壯夫

zhuoding hezhong 酌定合中

zhuoliang biantong 酌量變通

zongbing 總兵

zuofa 做法 